\title{
ANTIVIRAL ACTIVITY AND ITS MECHANISM OF GUANINE $7-N$-OXIDE ON DNA AND RNA VIRUSES DERIVED FROM SALMONID
}

\author{
Masahide Hasobe, Mineo Saneyoshi* \\ Faculty of Pharmaceutical Sciences, Hokkaido University, \\ Sapporo 060, Japan \\ and KIYOSHI IsONO
}

The Institute of Physical and Chemical Research

Wako-shi, Saitama 351-01, Japan

(Received for publication July 18, 1985)

\begin{abstract}
Guanine 7-N-oxide produced by Streptomyces sp. was found to inhibit in vitro the replication of herpes virus (Oncorhynchus masou virus, OMV), rhabdo virus (infectious hematopoietic necrosis virus, IHNV) and a bi-segmented double-strand virus (infectious pancreatic necrosis virus, IPNV) derived from salmonids with $\mathrm{IC}_{50}$ values of about $10 \mu \mathrm{g} / \mathrm{ml}, 20 \mu \mathrm{g} / \mathrm{ml}$ and 32 $\mu \mathrm{g} / \mathrm{ml}$, respectively. The agent was not toxic for the host cells (chinook salmon embryo, CHSE-214) at the $\mathrm{IC}_{50}$ concentrations.

Labeling of IHNV viral RNA and host cellular DNA and RNA with $\left[{ }^{3} \mathrm{H}\right]$ uridine and $\left[{ }^{3} \mathrm{H}\right]-$ thymidine during drug treatment showed that guanine 7- $\mathrm{N}$-oxide did not reduce the incorporation of these precusors into RNA and DNA.

The anti-IHNV activity of guanine 7- $N$-oxide was enhanced synergistically by neplanocin A, an inhibitor of RNA methylation.

The mechanism of action of guanine 7-N-oxide is discussed, in regard to maturation of viral messenger RNA including capping.
\end{abstract}

Recently, guanine 7- $N$-oxide, a new antibiotic produced by Streptomyces sp., has been discovered independently by two laboratories ${ }^{1,2}$.

This compound has shown inhibitory to Candida albicans but inactive against Gram-positive and Gram-negative bacteria and Trichophytons. It also inhibited Yoshida sarcoma and L-5178Y leukemia cells in culture ${ }^{1,2)}$. In this paper, we report for the first time the antiviral activity of guanine 7- $N$ oxide, particularly against several fish viruses.

Recently, we developed a convenient system for evaluation of anti-RNA viral compounds on a microtiter plate with 96 wells. Infectious hematopoietic necrosis virus (rhabdoviridae) ${ }^{5,8}$ ) is used as a probe for evaluation of the compound (namely, the CPE spot reduction method) ${ }^{3)}$; the method being quantitatively and reproducibly equal to standard plaque reduction methods.

Using CPE spot reduction method, guanine $7-N$-oxide was found first to have the anti-IHNV activity. We therefore examined the activity of guanine $7-\mathrm{N}$-oxide against infectious hematopoietic necrosis virus (IHNV) replication in cell culture. The antiviral spectrum of this compound was also studied using herpes virus (Oncorhynchus masou virus, OMV) ${ }^{8,0)}$ and a bi-segmented double-strand RNA virus (infectious pancreatic necrosis virus, IPNV) ${ }^{7 \text { ) }}$

Further, the combinations of guanine 7- $\mathrm{N}$-oxide with neplanocin A resulted in the synergistic antiviral activity against IHNV. Based on these observation, the mechanism of action of guanine 7 - $\mathrm{N}$-oxide is discussed. 


\section{Materials and Methods}

Cell and Viruses

Chinook salmon embryo (CHSE-214) cells ${ }^{4)}$, IHNV ${ }^{5,6)}$, IPNV ${ }^{7)}$ and $\mathrm{OMV}^{8,8)}$ were kindly supplied by Prof. T. KImura, Faculty of Fisheries, Hokkaido University. The method for cultivation of CHSE-214 cells and the propagation of IHNV were described previously ${ }^{3)}$. The stock viruses of IPNV and OMV were passaged three times in CHSE-214 cells and propagated in same cell line.

\section{Compounds}

A crystalline guanine 7- $N$-oxide (Gua-7-oxide) was prepared from Streptomyces sp. by the method reported previously ${ }^{1}$. Neplanocin A (Nep A) was supplied by Toyo Jozo Co., Ltd. And 9-methylguanine 7- $N$-oxide was synthesized chemically ${ }^{10)}$.

Determination of Antiviral Activity

The following techniques were employed for evaluating the antiviral activity of the test compound.

Cytopathic Effect (CPE) Spot Reduction Method: The CPE spot reduction method using microtiter plate with' 96 wells was employed for the evaluation of anti-IHNV activity and the combination investigation of Gua-7-oxide with Nep $\mathrm{A}^{3)}$. In brief, nearly confluent cells in a well of microtiter plate were infected with IHNV at a concentration forming CPE spots of about 100 per well. After the addition of culture media containing varying levels of the test compound, cultures were incubated for three days at $15^{\circ} \mathrm{C}$. After fixing and staining the CPE spots formed on cell monolayers were counted microscopically.

Plaque Reduction Method: The Plaque reduction method was used for the evaluation of the compound against IPNV and OMV. This method reported previously for the assay of IHNV was used in the case of IPNV and OMV with a slight modification ${ }^{3)}$. In brief, confluent cell monolayers in plastic dishs (35 $\mathrm{mm}$ diameter) were infected with $100 \sim 200$ plaque forming units of IPNV and $\mathrm{OMV}$ per well. After 1 hour adsorption at $15^{\circ} \mathrm{C}$, the inoculum was removed and the cultures were overlaid with maintenance media containing $0.75 \%$ agarose and an appropriate amount of Gua-7oxide. After incubation of 3 days for IPNV and 6 days for OMV, the fixed and stained plaques were counted microscopically.

Virus Yield Reduction Method: Confluent CHSE-214 cells in a plastic dishs (35 mm diameter) were infected with IHNV at multiplicity of injection (M.O.I.) $=0.01$. After 1 hour adsorption at $15^{\circ} \mathrm{C}$, cell monolayers were washed with culture medium; after washing, fresh culture medium with varying levels of Gua-7-oxide were added, and incubation was begun at $15^{\circ} \mathrm{C}$ during 5 days. Supernatant of the culture were centrifuged at $5,000 \mathrm{rpm}$ for 10 minutes, and then titered by the CPE spot assay method using a multidish with 24 wells reported previously ${ }^{3}$.

\section{Inhibition of Cell Growth}

The CHSE-214 cells were plated in $35 \mathrm{~mm}$ plastic dish at $6 \times 10^{5}$ cells per dish. After 1 day, culture media were exchanged with fresh growth media containing an approriate amount of Gua-7oxide. After the incubation at $15^{\circ} \mathrm{C}$ during 5 days, cells were dispersed by trypsin treatment, and the number of viable cells stained with trypan blue was determined with a hemocytometer.

\section{Viral RNA Synthesis and Cellular DNA and RNA Synthesis}

In the test of viral RNA synthesis, confluent CHSE-214 cells in a well of microtiter plate were inoculated with IHNV at M.O.I. $>1$. After the adsorption at $15^{\circ} \mathrm{C}$ for 1 hour, inoculum was discarded completely by aspiration. Then cells were added $100 \mu \mathrm{l} /$ well of maintenance medium containing an appropriate amount of compound and $1.5 \mu \mathrm{g} / \mathrm{ml}$ of actinomycin $\mathrm{D}$ (Act D) (Sigma). After the incubation at $15^{\circ} \mathrm{C}$ for 12 hours, $10 \mu \mathrm{l}$ per well of radioactive precusor $\left[{ }^{3} \mathrm{H}\right]$ uridine(Urd) (Amersham), $100 \mu \mathrm{Ci} / \mathrm{ml}$, was added in each well. After additional incubation for 3 hours, medium in a well was discarded, and cells were lysed with $50 \mu \mathrm{l}$ of $0.5 \%$ SDS solution containing $0.1 \mathrm{M} \mathrm{NaCl}, 5 \mathrm{~mm}$ EDTA and $30 \mathrm{~mm}$ Tris- $\mathrm{HCl}(\mathrm{pH} 9.0)$. After a pipetting by Gilson Pipetman, each lysing sample was applied on to DE-81 paper (Whatman), washed 5 times with $5 \% \mathrm{Na}_{2} \mathrm{HPO}_{4}$ solution, and immersed in ethanol, and ether. After drying, the radioactivity that remained on DE-81 paper was counted in 
a scintillation counter with toluene scintillator.

In the cellular DNA and RNA synthesis, non-infected cells in microtiter plate were labeled with $\left[{ }^{3} \mathrm{H}\right] \mathrm{Urd}, 2 \mu \mathrm{Ci} / \mathrm{ml}$, and methyl-[ $\left.{ }^{3} \mathrm{H}\right]$ thymidine(dThd) (New England Nuclear), $2 \mu \mathrm{Ci} / \mathrm{ml}$, for 3 hours at $15^{\circ} \mathrm{C}$ with or without test compound. The radioactivity incorporated into cellular DNA and RNA was measured by the same method described above.

\section{Combination Study of Guanine 7-N-Oxide with Neplanocin A}

The anti-IHNV activity of Gua-7-oxide combined with Nep A was examined by the CPE spot reduction method described above. The effect of this combination study was expressed graphically in statistically fitted isobolograms $\mathrm{s}^{11,12)}$. In brief, each $50 \%$ inhibitory concentration $\left(\mathrm{IC}_{50}\right)$ obtained from CPE spot reduction assay of Gua-7-oxide in combination was reexpressed as a fractional inhibitory concentration (FIC), that is, as a fraction of $\mathrm{IC}_{50}$ of Gua-7-oxide used alone (Gua-7-oxide $\mathrm{FIC}=$ Gua-7-oxide $\mathrm{IC}_{50}$ in combination/ Gua-7-oxide $\mathrm{IC}_{50}$ alone). The resulting Gua-7-oxide FIC was paired with the FIC of Nep A that was present in that combination (Nep A FIC $=$ concentration of Nep $\mathrm{A}$ in combination/ Nep $\mathrm{A} \mathrm{IC}_{50}$ alone). The FIC values for Nep $\mathrm{A}$, in the presence of each concentration, were determined by the same method described above.

\section{Results}

\section{Antiviral Activity}

Gua-7-oxide was tested for the anti-IHNV activity by CPE spot reduction method. The results was shown that $10 \mu \mathrm{g} / \mathrm{ml}$ of this compound was required to suppress CPE spot to $50 \%$ (Fig. 1). In addition, $\mathrm{IC}_{50}$ of this compound against IPNV and OMV was found to about $20 \mu \mathrm{g} / \mathrm{ml}$ and $30 \mu \mathrm{g} / \mathrm{ml}$, respectively (Fig. 1). That the inhibitory effects of Gua-7-oxide on viral CPE spot truly reflected the inhibition of IHNV replication was ascertained by a virus growth experiment. At a concentration of $12 \mu \mathrm{g} / \mathrm{ml}$, Gua-7-oxide caused a more than $1.5 \log _{10}$ reduction in the 3 days-yield of IHNV. At the dose of $50 \mu \mathrm{g} / \mathrm{ml}$, the virus yield was almost completely suppressed for 3 days (Fig. 2).

\section{Anti-cell Growth Activity}

Gua 7-oxide did not inhibit the growth of CHSE-214 cells at a concentration up to $12 \mu \mathrm{g} / \mathrm{ml}$, which

Fig. 1. Antiviral activity of guanine 7-N-oxide against IHNV (○), IPNV $(\bullet)$ and OMV ( $\triangle$ ), and the antiviral activity of 9-methylguanine 7 - $N$-oxide against IHNV ( $\mathbf{\Delta})$.

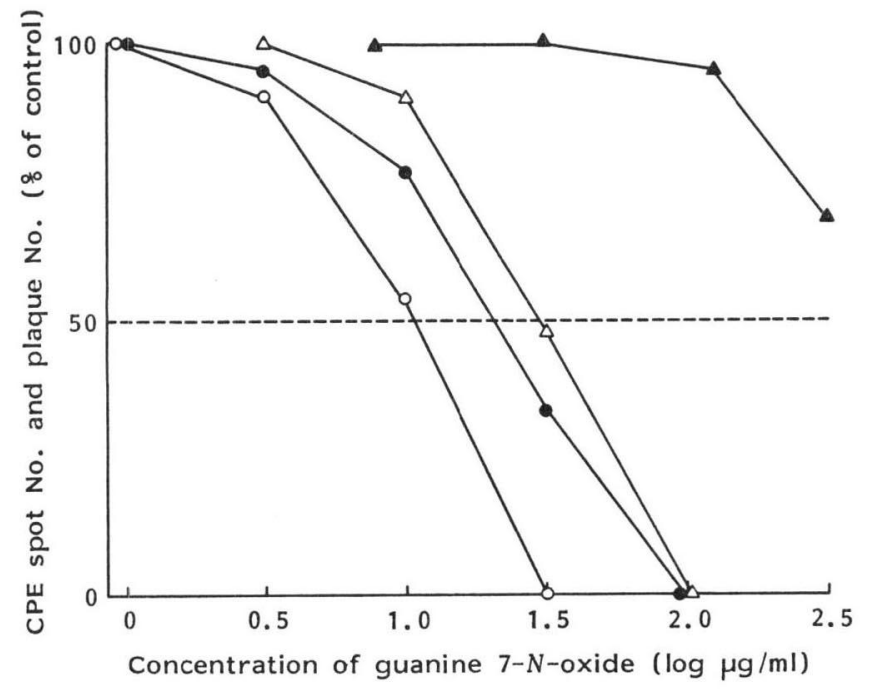


Fig. 2. The effect of guanine 7-N-oxide on IHNV viral yield.

$\bigcirc 0 \mu \mathrm{g} / \mathrm{ml}, \quad 3 \mu \mathrm{g} / \mathrm{ml}, \Delta 6 \mu \mathrm{g} / \mathrm{ml}, \Delta 12 \mu \mathrm{g} / \mathrm{ml}$, $\square 25 \mu \mathrm{g} / \mathrm{ml}$, 圆 $50 \mu \mathrm{g} / \mathrm{ml}$.

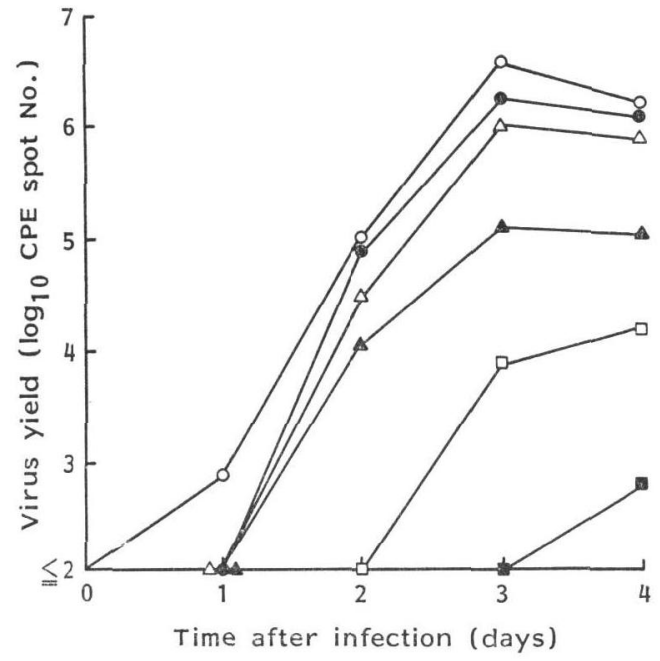

Fig. 3. The effect of guanine $7-N$-oxide on the growth of CHSE-214 cells.

$\bigcirc 0 \mu \mathrm{g} / \mathrm{ml}, \bullet \quad 6 \mu \mathrm{g} / \mathrm{ml}, \triangle 12 \mu \mathrm{g} / \mathrm{ml}, \Delta 25 \mu \mathrm{g} / \mathrm{ml}$, $\square 50 \mu \mathrm{g} / \mathrm{ml}$, 固 $100 \mu \mathrm{g} / \mathrm{ml}$.

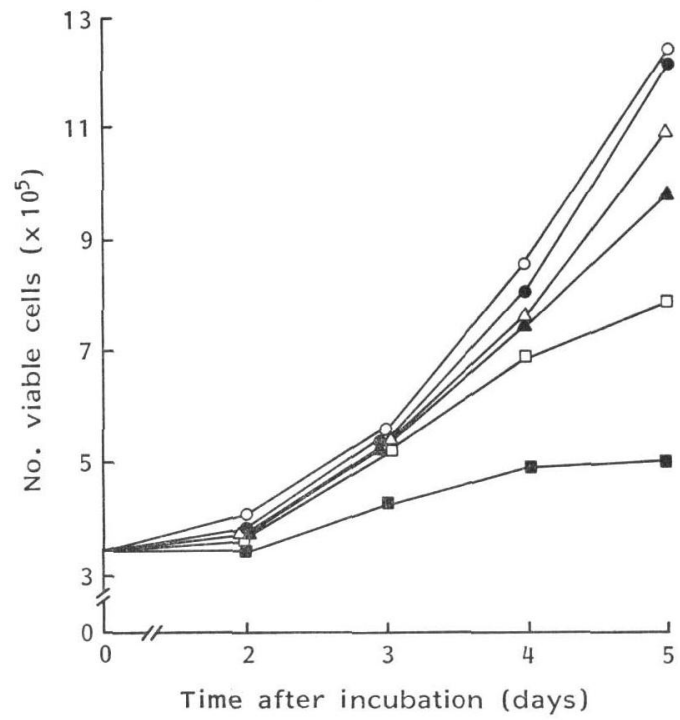

Fig. 4. The effect of guanine 7-N-oxide on IHNV viral RNA synthesis and cellular DNA and RNA synthesis.

The $100 \%$ incorporation of $\left[{ }^{3} \mathrm{H}\right] \mathrm{Urd}$ is the value subtracted the uninfected sample $(400 \mathrm{cpm})$ treated with Act $D$ from the infected sample $(6,100 \mathrm{cpm})$ treated with Act D.

0 : IHNV viral RNA, $\triangle$ : cellular DNA, $\mathbf{A}$ : cellular RNA.

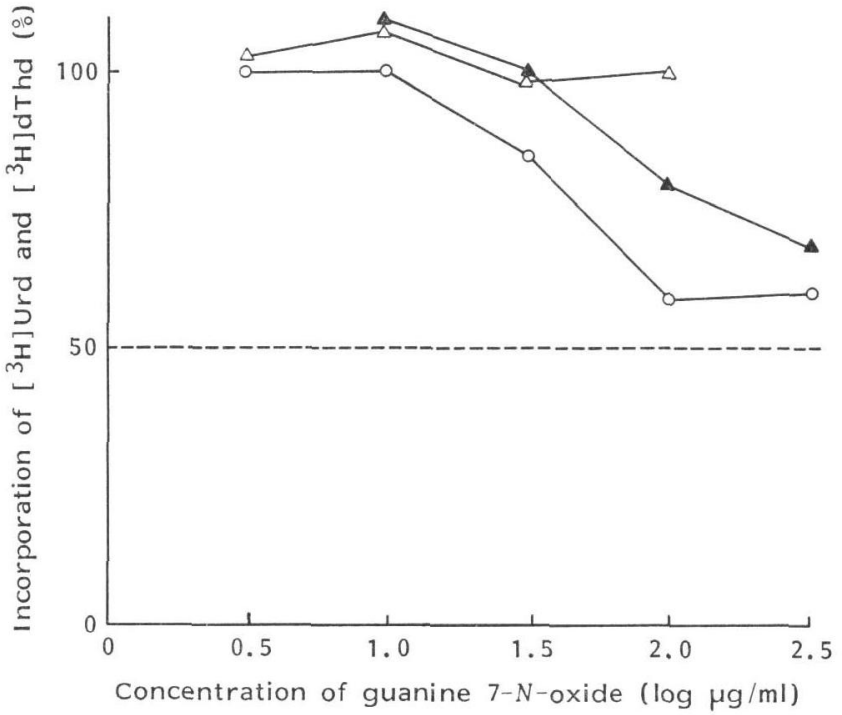

was the $\mathrm{IC}_{50}$ value of $\mathrm{CPE}$ spot reduction; $50 \mu \mathrm{g} / \mathrm{ml}$ was required to inhibit the cell growth by $50 \%$ (Fig. 3).

Influence of Viral RNA Synthesis and Cellular DNA and RNA Synthesis

In order to follow the viral RNA synthesis, actinomycin $\mathrm{D}(1.5 \mu \mathrm{g} / \mathrm{ml})$ was added to inhibit the 
Fig. 5. The anti-IHNV activity of guanine 7- $N$-oxide and Nep A singly and in combination.

A: CPE spot reduction assay, $\bigcirc$ : Nep A only, $\bullet$ : Nep A+Gua-7-oxide $(1 \mu \mathrm{g} / \mathrm{ml}), \triangle$ : Nep A+ Gua-7-oxide $(3.2 \mu \mathrm{g} / \mathrm{ml})$, $\mathbf{A}$ : Nep A+Gua-7-oxide $(10 \mu \mathrm{g} / \mathrm{ml})$.

B: Antiviral isobologram of Gua-7-oxide combined with Nep A.

A

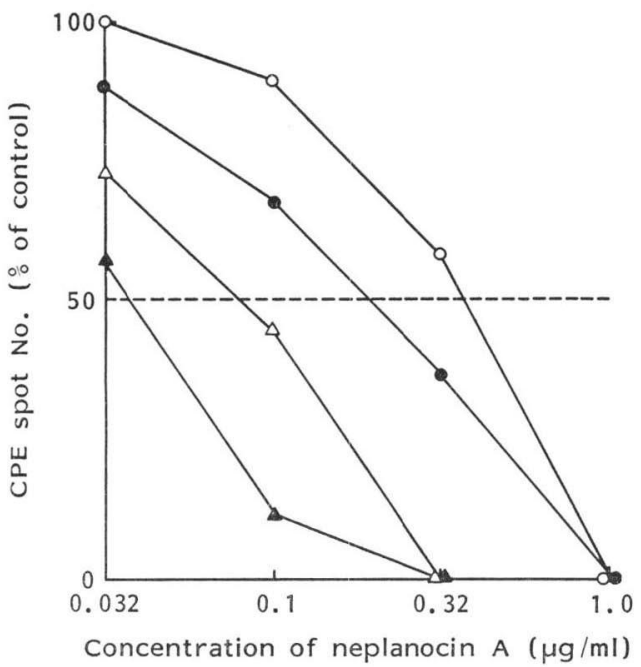

B

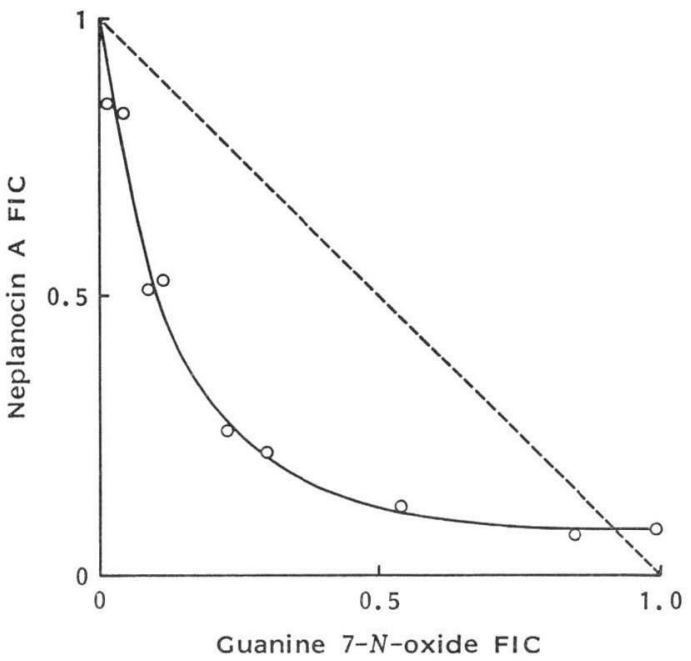

cellular RNA synthesis by $86 \%$ within 1 hour (data not shown). A peak of $\left[{ }^{3} \mathrm{H}\right]$ Urd incorporation into viral RNA appeared 12 15 hours post-infection (p.i.) at $15^{\circ} \mathrm{C}$ (data not shown). Therefore, the pulse labeling for 3 hours with precursor was performed 12 hours after infection.

As shown in Fig. 4, Gua-7-oxide scarcely inhibited the IHNV viral RNA synthesis at a concentration of $32 \mu \mathrm{g} / \mathrm{ml}$, which is the inhibitory concentration by $100 \%$ (MIC) of CPE spot with IHNV infection. Cellular DNA and RNA synthesis were also scarcely inhibited at a concentration as high as $32 \mu \mathrm{g} / \mathrm{ml}$.

\section{Combination Studies of Gua-7-oxide with Nep A}

The antiviral activity of Gua-7-oxide and Nep A combination against IHNV was expressed quantitatively as a CPE spot reduction curve. As can be shown in Fig. 5A, the anti-IHNV activity of Nep A combined with Gua-7-oxide was more effective than either compound alone. The addition of Gua-7oxide to $3.2 \mu \mathrm{g} / \mathrm{ml}$ enhanced $\mathrm{IC}_{50}$ level of anti-IHNV activity to MIC level. The drug combination is shown to be synergistic by isobolographic expression of antiviral activity (Fig. 5B).

\section{Discussion}

Gua-7-oxide has a broad antiviral spectrum against IHNV (rhabdo virus), IPNV (unclassified, a bi-segmented double-strand RNA virus) and OMV (herpes virus) derived from salmonids, with $\mathrm{IC}_{50}$ values about $10 \mu \mathrm{g} / \mathrm{ml} \sim 30 \mu \mathrm{g} / \mathrm{ml}$. In addition, the IHNV virus yield was reduced effectively at the $\mathrm{IC}_{50}$ level of the agent and the effect of drug on uninfected cell growth was not significantly affected. In the experiment of the incorporation of radioactive precursor, viral RNA, cellular DNA and RNA synthesis were scarcely inhibited at a concentration of as high as the $\mathrm{IC}_{50}$ value. In addition the combination of Gua-7-oxide and Nep A was shown to be synergistic in antiviral activity.

The antiviral mechanism of Gua-7-oxide is interesting. The viral RNA synthesis of IHNV was not significantly altered at the concentration of $32 \mu \mathrm{g} / \mathrm{ml}$ of this compound, which is the MIC value 
Fig. 6. Antiviral activity of neplanocin A against IHNV. O: CPE spot reduction. $\left[{ }^{3} \mathrm{H}\right] \mathrm{Urd}$ incorporation.

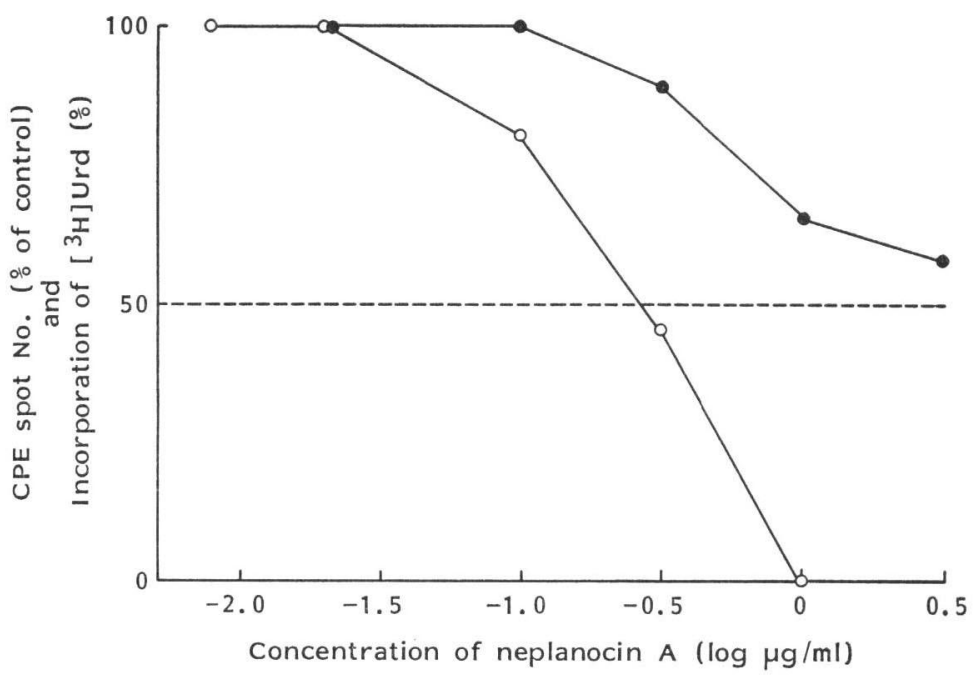

for IHNV. A similar effect was observed with Nep A (Fig. 6) which is an inhibitor of RNA methylation as described by GLAZER and $\mathrm{KNODE}^{13)}$. These results suggest that the mechanism of action of Gua-7-oxide may be the inhibition of mRNA maturation steps including the capping.

The activated form of Gua-7-oxide in antiviral action might be guanosine 7-N-oxide $5^{\prime}$-monophosphate formed by hypoxanthine/guanine phosphoribosyltransferase, because the 9-methylguanine $7-N$-oxide showed no anti-IHNV activity at a concentration of $100 \mu \mathrm{g} / \mathrm{ml}$ as shown the CPE spot reduction method (Fig. 1). Obviously, this compound can not be converted to the corresponding nucleotide.

The combination study was also suggestive for the mechanism of action of Gua-7-oxide. If the site and the mode of inhibition by both Gua-7-oxide and Nep A are the same, the combination would result in an additive response. The experimental results indicated the synergistic antiviral activity. Therefore, the mechanism of action of Gua-7-oxide is not totally the same as that Nep A. It should be noted that Gua-7-oxide may be regarded as an analog of 7-methylguanine in the cap structure (7mGpppNp) of eukaryotic and viral mRNA. Lack of the activity on prokaryotes of this compound also seems to support this presumption.

\section{Acknowledgment}

This work was supported in part by Grand-in Aid for Cancer Research from Ministry of Education, Science and Culture of Japan to M.S.

\section{References}

1) Nishi, M.; J. Inagaki, F. Nohara, K. Isono, H. Kusakabe, K. Kobayashi, T. Sakurai, S. Koshimura, S. K. Sethi \& J. A. MCCloskey: A new antitumor antibiotic, guanine 7 - $N$-oxide produced by $S$ treptomyces sp. J. Antibiotics 38: 1440 1443, 1985

2) Kern, D. L.; G. C. Hokanson, J. C. French \& N. K. Dalley: Guanine-7-oxide, a novel antitumor antibiotic. J. Antibiotics 38: 572 574, 1985

3) Hasobe, M. \& M. SANeyoshi: A new method for the evaluation of antiviral agents against infections hematopoietic necrosis virus (IHNV) on microtiter plates: CPE spot reduction method. Bull. Japan Soc. Sci. Fish. 51: 1079 1084, 1985

4) Lannan, C. N.; J. R. Winton \& J. L. Fryer: New cell lines. Fish cell lines: Establishment and char- 
acterization of nine cell line from salmonids. In Vitro 20: 671 676, 1984

5) McCain, B. B.; J. L. Fryer \& K. S. Pilcher: Physicochemical properties of RNA of salmonid hematopoietic necrosis virus (Oregon strain) (38161). Proc. Soc. Exp. Biol. Med. 146: 630 634, 1974

6) KuRAth, G. \& J. C. Leong: Characterization of infectious hematopoietic necrosis virus mRNA species reveals a nonvirion rhabdovirus protein. J. Virol. 53: 462 468, 1985

7) Mertens, P. P. C.; P. B. JAmieson \& P. Dobos: In vitro RNA synthesis by infections pancreatic necrosis virus-associated RNA polymerase. J. Gen. Virol. 59: 47 56, 1982

8) Kimura, T.; M. Yoshimizu \& M. TAnaka: Studies on a new virus (OMV) from Oncorhynchus masou. I. Characteristics and pathogenicity. Fish Pathol. 15: 143 147, 1981

9) Kimura, T.; M. Yoshimizu \& M. TanaKa: Studies on a new virus (OMV) from Oncorhynchus masou. II. Oncogenic nature. Fish Pathol. 15: 149 153, 1981

10) Brown, B.; D. Joseph, T. LeIGH \& M. L. Swain: Synthesis and reaction of 7,8-dihydro-8-methylpterin and 9-methyl-guanine-oxide. J. Chem. Soc. Perkin Trans. I 1977: 1003 1009, 1977

11) Berenbaum, M. C.: A method for testing for synergy with any number of agents. J. Infect. Dis. 137: $122 \sim 130,1978$

12) Kirsi, J. J.; P. A. McKernan, N. J. Burns, III, J. A. North, B. K. Murray \& R. K. Robins: Broadspectrum synergistic antiviral activity of selenazofurin and ribavirin. Antimicrob. Agents Chemother. 26: $466 \sim 475,1984$

13) Glazer, R. I. \& M. C. KNode: Neplanocin A. A cyclopentenyl analog of adenosine with specificity for inhibiting RNA methylation. J. Biol. Chem. 259: 12964 12969, 1984 